University of Nebraska - Lincoln

DigitalCommons@University of Nebraska - Lincoln

To Improve the Academy

Professional and Organizational Development Network in Higher Education

1996

Dan Tries Problem-Based Learning: A Case Study

Harold B. White III

Follow this and additional works at: https://digitalcommons.unl.edu/podimproveacad

Part of the Higher Education Administration Commons

White, Harold B. III, "Dan Tries Problem-Based Learning: A Case Study" (1996). To Improve the Academy. 370.

https://digitalcommons.unl.edu/podimproveacad/370

This Article is brought to you for free and open access by the Professional and Organizational Development Network in Higher Education at DigitalCommons@University of Nebraska - Lincoln. It has been accepted for inclusion in To Improve the Academy by an authorized administrator of DigitalCommons@University of Nebraska - Lincoln. 
White, H. B. (1996). Dan Tries Problem-Based Learning: A Case Study. In L. Richlin (Ed.), To Improve the Academy, Vol. 15 (pp. 75-91). Stillwater, OK: New Forums Press and the Professional and Organizational Development Network in Higher Education. Key words: Case Study, Problem-Based Learning.

\section{Dan Tries Problem-Based Learning: A Case Study}

\section{Harold B. White, III}

University of Delaware

Problem-based learning approaches to education often generate justifiable enthusiasm among faculty who have become frustrated with the limitations of traditional lecture-based education. However, faculty contemplating a change to a problem-based format rarely anticipate the many practical difficulties that can destroy one's enthusiasm and create chaos in the classroom. This case study, about the trials and tribulations of a fictional anthropology professor, attempts to alert faculty who are interested in trying the method to some of the unexpected challenges they might encounter.

\section{Institutional Change in Instruction}

Adopting a radically different approach to teaching and learning involves considerable risk. Faculty developers need to be aware of the challenges and provide support for their colleagues who pursue new directions. Successful experiences can vitalize individuals and catalyze institutional change in the educational environment; but failure can be deadening. For most faculty, problem-based learning is a radically different approach to instruction that requires encouragement and support. 
Several years ago, guided by faculty from the University of New Mexico School of Medicine, a joint Medical Scholars Program between the University of Delaware and Thomas Jefferson Medical College (Blacklow \& Engel, 1991) introduced a few problem-based courses into the undergraduate curriculum for selected premedical students. Since then, with the help of workshops sponsored by the University's Center for Teaching Effectiveness and a grant from the National Science Foundation's Division of Undergraduate Education, problem-based learning has captured the imagination of both science and nonscience faculty (Groh, et al., 1996). Over 50 academic units have been represented among the 175 faculty and administrators attending the workshops. More than $\mathbf{3 0}$ have incorporated the approach into their courses across campus in the past two years. The interest continues to grow and the limits of the method are being explored on many fronts.

\section{What is Problem-Based Learning?}

The distinction between problem-based learning and other forms of cooperative or active learning often are blurred because they share certain common features and hybrid approaches abound as instructors adapt methods for particular situations. However, an essential component of problem-based learning is that content is introduced in the context of complex real-world problems. In other words, the problem comes first (Boud, 1985; Boud \& Feletti, 1991; Woods, 1985). This contrasts with prevalent teaching strategies where the concepts, presented in a lecture format, precede "end-of-the-chapter" problems. In problem-based learning, students working in small groups must identify what they know, and more importantly, what they don't know and must learn (learning issues) to solve a problem. These are prerequisites for understanding the problem and making decisions required by the problem. The nature of the problems preclude simple answers. Students must go beyond their textbooks to pursue knowledge in other resources in between their group meetings. The primary role of the instructor is to facilitate group process and learning, not to provide easy answers. With the change in format come different forms of assessment such as group examinations. 
The model for problem-based learning comes from a few medical schools, notably McMaster (Barrows \& Tamblyn, 1980), where, more than 25 years ago, they questioned how well traditional preclinical science courses trained physicians to be problem-solvers and life-long learners. Information-dense lectures presented by a series of content experts to large student audiences seemed disconnected from the practice of medicine that required integration of knowledge, decision making, working with others, and communicating with patients. The curricula of several medical schools now include problem-based, preclinical science courses. The effectiveness of the problem-based learning approach in the medical school environment has been debated, evaluated, and given qualified endorsement based on a limited number of studies (Albanese \& Mitchell, 1993; Berkson, 1993; Vernon \& Blake, 1993; Blake et al., 1995).

\section{Why Problem-Based Learning?}

Many of the concerns that prompted the development of problem-based learning in medical schools are echoed today in undergraduate education. Content-laden lectures delivered to large enrollment classes typify science courses at most universities and many colleges. Professional organizations, government agencies, and others call for a change in how science is taught as well as what is taught (Czujko, 1994; Project Kaleidoscope, 1991; Tobias, 1990, 1992; Wingspread Conference, 1994). Problem-based learning addresses many of the concerns. Above all it encourages students to take charge of their education. It emphasizes critical thinking skills, understanding, learning how to learn, and working cooperatively with others. While problem-based learning is well known in medical education, it is almost unknown in the undergraduate curriculum.

At the University of Delaware problem-based learning has been introduced in a number of undergraduate courses across the curriculum, not just in the sciences. The conceptual principles apply in international relations (Burch, 1995) as well as art history (ParkerMiller, 1996). In order to keep faculty here and elsewhere informed of problem-based activities and resources, a PBL homepage has been created which contains a directory of University of Delaware courses 
that use problem-based learning, faculty contacts, some examples of syllabi and problems, and links to other national and international sites. The address is: http://www.physics.udel.edu/ pbl/.

\section{The Case}

Because the use of problem-based learning is relatively new in the undergraduate setting, it is not known whether it achieves the desired long term objectives. Nevertheless, two-day workshops that demonstrate problem-based learning with students working in groups on actual problems frequently generates faculty enthusiasm resembling a religious conversion. They see the potential for the method. However, that enthusiasm must be tempered with the realization that many difficulties and challenges accompany the use of problem-based learning, particularly for the first time. For example, instructors usually must create their own problems without a full understanding of the important components and the time required. Frequently, there is a lack of support from colleagues who don't understand the method. Furthermore, most classrooms do not lend themselves to a problembased learning format.

"Dan Tries Problem-Based Learning" that follows is an extended case intended to confront prospective users with the spectrum of issues one might encounter in a semester that one normally would not encounter using a lecture format in a traditional class. The intent of the case is not to discourage but to have prospective users reflect more deeply about what is involved. While the entire case has not been used at one time, segments of it have served effectively at conference sessions devoted to different aspects of problem-based learning. I hope that the case will be useful to faculty developers elsewhere who have faculty interested in trying problem-based learning. As with many cases based on actual events, the names and situations have been fictionalized.

\section{References}

Albanese, M.A., \& Mitchell, S. (1993). Problem-based learning: A review of literature on its outcomes and implementation issues. Academic Medicine, 68, 52-81. 
Barrows, H.S., \& Tamblyn, R.M. (1980). Problem-based learning: An approach to medical education. New York: Springer.

Berkson, L. (1993, October). Problem-based learning: Have expectations been met? Academic Medicine, 68, 579-588.

Blake, J.M., Norman, G.R. \& Smith, E.K.M. (1995). Report card from McMaster: Student evaluation at a problem-based medical school. The Lancet, 345, 899-902.

Blacklow, R.S., \& Engel, J.D. (1991). The University of Delaware/Jefferson Medical Scholars Program: An approach to educating physicians for academic leadership and practice. Delaware Medical Journal, 63, 303-307.

Boud, D. (Ed.). (1985). Problem-based learning for the professions. Sydney: HERDSA.

Boud, D., \& Feletti, G. (Eds.). (1991). The challenge of problem-based learning. New York: St. Martin's.

Burch, K. (1995). PBL and the lively classroom. About Teaching, 47, 2.

Czujko, R. (1994). Physics job market: A statistical overview. AAPT Announcer, 24, 62.

Groh, S.E., Williams, B.A., Allen, D.E., Duch, B.J., Mierson, S. \& White, H.B., III. (1996). Institutional change in science education: A case study. In A.P. McNeal \& C. D'Avanzo (Eds.) Student-active science: Models of innovation in college science teaching. Philadelphia: Saunders.

Parker-Miller, M. (1996). Introducing art history through problem-based learning. About Teaching, 50, 3

Project Kaleidoscope. (1991). What works: Building natural science communities. Vol. One. Washington, D.C.: Stamats Communications.

Tobias, S. (1990) They're not dumb, they're different. Tuscon, AZ: Research Corporation. Tobias, S. (1992) Revitalizing Undergraduate Science. Tuscon, AZ: Research Corporation.

Vernon, D.T., \& Blake, R.L. (1993). Does problem-based learning work? A meta-analysis of evaluative research. Academic Medicine, 68, 550-563.

Wingspread Conference. (1994). Quality assurance in undergraduate education: What the public expects. Denver: ECS.

Woods, D. (1985). Problem-based learning and problem-solving. In D. Boud (Ed.) Problem-based learning for the professions, 19-42. Sydney: HERDSA.

Contact:

Harold B. White

Department of Chemistry \& Biochemistry

University of Delaware

Newark, DE 19716 USA

(302) 831-2308

(302) 831-6335 FAX

Harold B. White is professor of biochemistry in the Department of Chemistry and Biochemistry at the University of Delaware where he has helped students learn 
since 1971. Currently he is Chair of the Faculty Advisory Board for the university's Center for Teaching Effectiveness and a member of the education committees for both the American Society for Biochemistry and Molecular Biology and the American Entomological Society. In addition to a strong interest in adapting problem-based learning for undergraduate instruction, he supervises research on vitamin-binding proteins, contemplates issues in molecular evolution, and pursues dragonflies with camera and net in his spare time.

This work was supported in part by Grant DUE-9354606 entitled "Problem-Based Learning in Introductory Science Across Disciplines" from the National Science Foundation. I thank Deborah Allen, Barbara Duch, Susan Groh, Sheella Mierson, David Onn, and Barbara Williams, my co-Principal Investigators on this grant, whose diverse backgrounds and interests have combined to enrich a shared goal of improving undergraduate education. I also thank George Watson for setting up our PBL homepage. 


\section{Appendix A}

\section{Dan Tries Problem-Based Learning}

\section{Getting Started With Problem-Based Learning}

Dan Sherman had spent his entire academic career of almost two decades in the anthropology department of a mid-sized university. Of all the courses he taught, Anthropology 255 Readings in Anthropology for the 25 to 30 sophomore anthropology majors, was his favorite. The course demanded hard work and emphasized thinking. Dan's lectures focused on basic themes in anthropology and the connections between various subdisciplines of anthropology. Students consistently rated the course highly. They liked Prof. Sherman's casual style, his enthusiasm for the subject, and his obvious interest in the personal development of each student.

Despite the uniform praise he received from students and faculty, Dan always sensed he could do better. Too many of his former students, even honors students, had graduated with a superficial understanding or outright misunderstanding of fundamental concepts of anthropology that he had covered thoroughly in his course. To him many of these graduates seemed to lack the enthusiasm for continued learning that would carry them to successful careers. He believed that a truly excellent teacher could change this situation. Furthermore, he was beginning to worry whether his excellent teaching ratings reflected the student's appreciation of him rather than what he was teaching. Perhaps in frustration and partly out of curiosity, Dan decided a radically different approach was needed for his teaching. What harm could it do?

Dan had read about problem-based learning as it was used in medical schools. It seemed that the pedagogical principles of that approach could apply anywhere, including anthropology. After discussing "PBL" with a few colleagues who had tried the approach in other disciplines, he took the plunge and revamped ANTH 255 completely. No longer did he lecture. Rather he used class time to move among groups of four or five students who were discussing classic articles in anthropology that he had carefully selected and assigned. 
That happened a year ago. There were still bugs to work out. He knew that some things hadn't gone as planned and that there had been a lot of confusion initially until he and the students recognized what it was they needed to do. He had anticipated there would be some difficulties because students were not used to taking as much responsibility for their own learning and many students (and some of his colleagues) felt that, "If you don't lecture, you're not teaching." Now that he had a year of experience, he was all charged up to do it again, only better. His revised syllabus was ready and the schedule was set. He could hardly wait to get the course rosters so he could assign students to groups and get started.

What decisions related to organization and process would you need to make if you were going to follow Dan's lead and give problem-based learning a try?

Some of Dan's colleagues worry that Dan covers less material using PBL. How should Dan respond to those concerns?

How did Dan's course change as a result of using problem-based learning? What didn't change?

\section{Constructing Groups}

A total of 27 students had pre-registered for Dan Sherman's ANTH 255 Introduction to Anthropology class. He noted that three of them were not anthropology majors. This, he mused, was a common problem. Every year, it seemed, there were a few students who did not read the course description and registered for his course mistakenly thinking it would satisfy a general education requirement. If they show up at all, they would undoubtedly drop after the first class when they found out the course is required only for majors. For the remaining students, Dan had available SAT scores, GPA's, grades in the introductory anthropology courses, their race and gender. He proceeded to assign students to different groups with the objective of maximizing heterogeneity without making any group academically unbalanced. He was particularly pleased to see so many honors students registered. There were enough to have at least one, and sometimes two, in each group. After three hours of shifting and balancing, he felt he had made five well balanced but heterogeneous groups. The average GPA for 
all of the students combined was within a tenth of a point of the average GPA of the students in any one of the groups. Minority students were represented in each group. No identifiable type of student was concentrated in any particular group.

Later Dan began to wonder whether it was worth the effort. Was he fooling himself to think that he could take a few pieces of information about each student and be able to create groups that would function well for the whole semester? Maybe he should just assign students randomly or let students choose their own groups.

What are the advantages and disadvantages of forming groups the way Dan did? Should Dan let students form their own groups?

Are there types of information you would not have used or other information you would want to use in constructing groups?

\section{The First Class}

Dan knew that the first day of class was the most important of the whole semester. It set the tone for the whole semester. Consequently, he did not want to repeat last year's mistake of lecturing about the course for the whole period. That sent entirely the wrong message, yet he still wanted to communicate what the course was about and how it was likely to be different from any other course they had encountered. He had thought this all through and was ready.

It was raining when he arrived half an hour early for the 8 a.m. class. On the board he listed the students who were in each group. He arranged the tables and chairs in this new room specifically set up for PBL teaching. (It had been a mess last year in a traditional classroom where the students didn't have room to spread out their things.) The first student arrived ten minutes before class. Dan greeted her, handed her a syllabus, asked her name, and pointed to the table where her group would be. As more students came he repeated the personal greeting and also suggested that the students in each group get to know each other because they would be together for the rest of the semester and later that period each would have to stand up and introduce a fellow group member. Because this was the first meeting of the semester, Dan waited a few extra minutes for stragglers so they 
wouldn't be left out even though normally he started classes right on time.

At 8:10 five students were still missing. (They never showed up.) Unfortunately three were from one of his planned groups. All of the non anthropology majors showed up. It turned out they planned to become anthropology majors but had not yet processed their changeof-major form. In order that he would have functioning groups, he tentatively assigned all three to the group with the missing members. Under his breath he recited Robert Burns' line about the best laid plans of mice and men. Nevertheless he forged ahead with his plan and had each student stand up and introduce the next person. This proved to be a traumatic experience for several students. Lisa, for example, was very shy. Her whisper hardly could be heard above the whir of the ventilator fan in the room. Anna had been in this country only a few years and clearly was uncomfortable speaking publicly. Jason, on the other hand, enjoyed the limelight and introduced the next student with some ill-considered "joke" about his new friend from the ghetto. After what seemed like a very long 15 minutes, Dan explained the assignment for the rest of the period.

Should Dan have done anything differently? What?

\section{First Class Student Concerns}

Dan had each group read the syllabus with the objective of making a list of at least five items - either suggestions for improving the syllabus or questions about the course that were not answered to their satisfaction in the syllabus. After a few minutes of silence, the chatter of each group began and continued until the end of the period. Dan moved from group to group listening to the discussion and answering questions, usually with other questions that pointed the discussion in the right direction. While he had no trouble fielding the questions from each group as he visited it, his attention was distracted once when he heard some hostile remarks from another group nearby.

"This, like, sucks. Really, I mean, if this guy expects me to be here at eight every morning ready to participate in some geek discussion, he's gotta be crazy. My roommate had this kind of class last semester and said the prof didn't do anything. Like, he just used the group 
discussions to get out of teaching." (Another male student) "Yeah, and if this weren't a required course, I'd drop it now. I don't know about the rest of you guys, but I'll be happy to get a 'C.' Don't plan on me to bust my butt in the library every weekend." June, one of Dan's outspoken academic advisees, responded, "But that's unfair, if my grade depends partly on you. Why did you come to college in the first place? Maybe you ought to drop!" Several students said they would rather choose their own groups.

At the end of class, Dan collected the lists from each group and returned through the rain to his office where he planned to read the lists and reflect on the first class.

Was a critique of the syllabus a good group activity for the first day of class?

What might Dan have done to make the first class better?

Were the comments he overheard legitimate student concerns? How should he deal with them?

\section{Picking up the Pieces}

About 9:30, Jeff, an honors student who had missed class, appeared at Dan's office. He wanted a syllabus and asked if he had missed anything. Dan worked hard to conceal his anger. He asked Jeff why he had missed class. Jeff said he thought nothing important ever happens during the first class. All the professor does is hand out the syllabus, waste time talking about what everybody could read, and then dismiss class early. He then added that he celebrated the end of vacation last night, had gotten in late, and decided to sleep in when he saw it was raining. Dan was amazed by this frankness but he could see Jeff might be a big problem. Groups depend on mutual responsibility. When someone like Jeff feels he doesn't have to show up or doesn't do an assignment, it creates friction within a group.

What should Dan say to Jeff?

\section{Preparing for the Second Class}

The group responses to the syllabus revealed a general concern. Students wanted to know why so much of their grade $(20 \%)$ was for "appa" - attendance, preparation, participation, and attitude. Why, 
they asked, should they be graded on such things which, with the exception of attendance, were subjective and seemed irrelevant to course content? Why wasn't there a textbook? How many absences would be allowed before it affected one's grade? Was it really necessary to spend a whole class period on how to use the library because everything was easily accessible by computer? What did he mean by a "learning issue?" One group felt it was unfair to have part of one's grade be dependent on the performance of other people in the group particularly if some people were satisfied with a " $\mathrm{C}$ " and others were willing to work for "A's." Wouldn't the students learn more if he would simply lecture about each article and tell them what was important? What would the tests be like? Why was ANTH 255 a required course but was not a prerequisite for any other course?

How should Prof. Sherman respond to these issues at the next class?

\section{Problems with the Groups}

Five weeks had passed. The class was reading the third article. By now Dan knew each student and each group well. Each group had developed a character of its own. In general, Dan thought the class was going well. Compared to the previous year, he was more directive and he thought it made things better. There was less confusion about the roles of the student and the instructor. After completing each article, he lead a discussion with the whole class that dealt with the article's significance. The students participated and made comments that showed a real depth of understanding. His major concerns at this point had nothing to do with content. Two of his five groups showed signs of tension. He had received e-mail messages from several students who wanted to talk with him privately.

As Dan had dreaded, Jeff continued to miss class about once a week. In the same group, Joan had missed four classes due to a broken leg. The remaining students resented Jeff because he disrupted the activities of the group. When he wasn't there he couldn't contribute and couldn't be assigned learning issues to look up. When he was there, other group members thought they wasted valuable time explaining what they had gone over the class before. This was especially 
annoying because Jeff was probably the brightest person in the group and easily could have helped the group considerably. One student asked if it were possible to kick someone out of the group or exclude someone from the group part of the midterm exam. Dan had to think about that.

The other problem group included Jason, Anna, and Jamal. Anna was used to working hard and prepared thoroughly for each class. In most courses she quickly determined what the professor wanted, anticipated test questions, and was used to getting good grades. She claimed that "group assignments" were mostly her work and she complained that some of the students came to class without having read the assigned article. Those students expected the other students to tell them what was important. Jason jumped to conclusions, generated incorrect explanations that seemed plausible, dominated discussions, and didn't listen very well to alternate points of view. Jamal seemed to talk a lot but treated things rather superficially.

Characterize the situations in the two problem groups.

What could Dan have done to avoid these problems?

What should Dan do now?

\section{Planning the Midterm Examination}

Several students wanted to know, "What will be on the midterm?" Dan suggested that they look at last year's midterm at the back of their course reader. He said that their examination would be totally different from any examination they had ever had and that it would stress thinking, conceptualization, communication, and group processes.

One week before the midterm examination he gave the students a new article to read. Most of the midterm would relate to this article. The groups could use any of the resources at their disposal to prepare for the examination. Resources could include other faculty in the university, students in other groups, books in the library, and the Internet. Their goal was to use the skills they had learned to understand the article thoroughly in the week they had before the examination.

Such an examination could not be completed in a single one hour class period as Dan had painfully discovered last year. In order to allow for "unlimited" time for part 2, he scheduled the examination in the 
evening starting at 7 o'clock. The first part of the examination (50\%) would have four questions to be done individually and handed in. The second part would take the last of the four questions, which was also the most difficult question from the first part, and open it up to group analysis and discussion. The question for the group part was especially important. It had to be sufficiently difficult that few, if any, students would be certain of the answer when they answered it individually in part one. On the other hand, it couldn't be too difficult or the synergistic benefits of group work would not be apparent.

Throughout the course Dan had stressed again and again to the students the importance of being able to define as precisely as possible what they didn't know but needed to know to understand an article. These were the learning issues that they had to pursue in the library and elsewhere in their efforts to comprehend each article. It was Dan's firm belief that no matter how well someone understood an article, there would be still more learning issues to pursue. This was true for him because every time he reread these articles he saw something new he hadn't appreciated before. To address this aspect of the course, the first question on the individual part of the examination asked every student to make a list of their remaining learning issues, ranked in order of importance, and justified with respect to their importance. Dan got a perverse pleasure out of asking this question for $20 \%$ of the examination grade because it permitted students to get credit for identifying what they didn't know. As he said to the students, "Knowing what you don't know, in a sense, means you know everything." Such knowledge was power because it focused one's learning where it had the most impact.

What issues did Dan's examination address that aren't normally addressed in a midterm examination?

What problems might be anticipated with this type of examination?

\section{Grading the Midterm Examination}

Dan thought the examination went really well. Everybody seemed to participate. Students debated issues back and forth. Nobody left 
early. In fact, the last group left at 10:40! Now while the students were off enjoying their Spring Break, Dan faced several days of grading.

For many years, Dan had rejected multiple choice and short answer examinations because he felt they didn't reveal how much the students really understood. But grading essay examinations was painful and time consuming. He concluded that there was no way to evaluate answers objectively. Some students seemed to understand but they couldn't communicate their understanding. Some students took paragraphs to explain what others could say in a sentence. How should he deal with peripheral misinformation or beautifully written wrong answers? How could he explain to a student why the "quality" of his answer was poor? Dan read and reread each answer, compared student answers, and finally assigned numerical grades to each answer. A real dilemma arose when Dan graded the group part of the examination. Jason's group had completely blown the second part of the examination. They got only 20 out of 50 points. Everybody's answer read the same and their group answer was almost the same as Jason's answer to that question on the individual part of the examination. Was it fair to add the grades from both parts of the examination? After all there was an element of chance here and why should everyone in a group be penalized? Most of all Dan was concerned about Anna. She had done rather well on the individual part of the examination but, when the group part was added to her grade, she was in the bottom $25 \%$ of the class. He knew this would upset her totally. Furthermore it didn't reflect what she had learned in the course or the contributions she had made to the group.

Jeff's group revealed another pattern. After discussing the group problem, they couldn't come to agreement and so they decided to hand in individual answers. Although there were similarities, each student's answer on the group part was distinct. Jeff in fact had done very well - the best in the group. Apparently he couldn't communicate or couldn't convince his group of the correctness of his answers. Considering Jeff's frequent absences, it didn't seem fair that he got one of the highest scores in the class.

Did the midterm examination test what Dan wanted it to test?

Why did Anna do better on the individual part of the examination? 
Are the patterns on the group part of the midterm related to the difficulties within the groups prior to the examination?

\section{Grading Students and the Professor}

The final examination followed the format of the midterm examination except that Dan asked each group to analyze and interpret results from an article they had not seen before but which related to several conceptual themes followed through the course. He had told them to expect such a question. The students performed very well and their grades reflected that. Seventy-two percent of his class got A's or B's. That compared with only $45 \%$ in the previous year. Dan struggled with this apparent grade inflation and so did his chairman. Had he lowered his standards? Did he need to raise his standards? Would it be fair to students who had taken the course previously but had suffered because he had not handled group process issues very well? Would his colleagues think he was getting soft and had confused content issues with process issues?

Two weeks after the end of the semester, the chairman, who had noticed the increase in the student's grades, called Dan into his office. He wanted Dan to explain why the grades this year were out of line with the grades he had given in previous years. In addition, he showed Dan an anonymous letter written by a student who complained that Prof. Sherman expected students to learn on their own and to spend too much time in the library tracking down obscure facts. The student also said that the grades were totally subjective and didn't reflect what each student knew or had learned in the course.

Were the chairman's concerns about the higher grades Dan gave this year legitimate?

How should Dan respond to the chairman's questions and the student's letter?

\section{Student Evaluations}

Dan compared the student responses this year to those of the last year, when he first used problem-based learning, and to earlier years when the course had a predominantly lecture format. While the evaluations improved over the previous year and were generally good, 
they were not as good as when he had lectured. This troubled him because it seemed that the course in its current format was superior to the earlier format. If this were a general phenomena reflecting some reluctance by students to take responsibility for their learning, would other faculty really want to jeopardize their ratings in a change to a problem-based approach? Considering the midterm fiasco and the group component of each student's grade, Dan could understand why the students felt uncertain about what grade they would get in the course, and he wondered whether that concern influenced their responses to other questions.

Should Dan return to a lecture format the next time he teaches ANTH-255? 